\title{
PRODUCTION AND EVALUATION OF SYCAMORE AND FIG BLENDS JAM
}

\author{
ABD-EL-HAK, NASRA A., HANAA S. M. ABD EL-RAHMAN and AYAT E. RIZK
}

Food Technology Research Institute, ARC, Giza, Egypt

(Manuscript received 3 March 2016)

\begin{abstract}
$\mathrm{T}$ his research aimed to use sycamore and fig fruit in processing of jam. Sycamore and fig were blended in the ratios of 100:0, 0:100, 20:80, 80:20 and 50:50 respectively to prepare jam blends. jam samples were evaluated for chemical and sensory characteristics. The prepared jam samples stored for 12 month at room temperature $\left(25-30^{\circ} \mathrm{C}\right)$,during which they were analyzed for total sugar and some physicochemical characteristics $(\mathrm{pH}$, total soluble solids and viscosity). The obtained results showed that sycamore was rich in ash and crude fiber. The sensory properties were also improved as the proportion of fig content was increased up to $50 \%$ of the blend. As the period of storage increased the acidity decreased in jam, besides improving the physiochemical properties. Therefore, from the results, one may recommend that the use of sycamore and fig blends in jam production is recommended to increase nutritional value. This would also increase the utilization of sycamore. And also, we recommend expanding the cultivation of sycamore trees in the new reclaimed lands and its use in food processing and pharmaceutical product.
\end{abstract}

Key words: sycamore, fig, jam , sensory evaluation ,total soluble solid and viscosity.

\section{INTRODUCTION}

In Egypt, many Ficus species are found in streets, gardens and parks. The fruits of $F$. carica L. and F. sycomorus $L$. are two of the most favorable fruits eaten by Egyptian peoples. Ficus sycomorus L., a medicinal plant belonging to the family Moraceae comprises about 755 fig tree species worldwide (Van Noort et al., 2007). F. sycomorus L. is widely distributed in tropical West Africa and grown in the Mediterranean basin of Egypt since antiquity and is known for their medicinal and aromatic properties. Ficus sycomorus L. is cultivated in Egypt and called sycamore or gimmeiz. The leaves and fruits have been used in the treatment of tuberculosis, inflammations, dysentery, diarrhea, cough and chest diseases (El-Sayyad et al., 2014).

In 2005, around 25000 tons of mulberries (Morus alba) have been produced on 1059 hectares of plantations in Egypt for a value of 3,775 million and another 25 000 tons of fruits from Ficus sycamorus for a total value. Most of these fruits are consumed by local communities and just a little part of it is sold on the markets as 
reported by FAO, (2010). The sycamore provides water, vitamins, carbohydrates, minerals and pigments that are required in the diet (Rodriguez-García et al., 2007).Also, they reported that the fig is a very nourishing food and used in industrial products. It is rich in vitamins, minerals, water and fibers. Figs are one of the highest plant sources of calcium and fiber. Ramdu -Tiendrebeogo et al., (2012) found that the highest content in total phenolics and tannins and the best antifreeradical activity were obtained with sycamore. The consumption of fruits and vegetables has been associated with a low incidence of degenerative diseases due to protective effects associated with the antioxidant components contained in these foods (Rafael et al.,2013).

The aim of this study was to prepare jam from sycamore or fig blends.The processed jam was analyzed for chemical, physical and sensory characteristics. The effect of storage is at room temperature for 12 month on the quality of processed jam.

\section{MATERIALS AND METHODS}

\section{MATERIALS}

Fig (Ficus carica L) and sycamore (Ficus sycomorus L) fruits were purchased from the local market during their ripening season (2014). All of the ingredients (sugar and lemon) used for the jam preparation were obtained from the local market at Cairo, Egypt.

\section{METHODS}

\section{Jam preparation}

Selected fig and sycamore fruits were cleaned and washed. The fruits were cut into small pieces with stainless steel knife. $1000 \mathrm{~g}$ of the fig and sycamore were mixed with sugar and left at room temperature for 1 hour. The mixture of fig, sycamore, sugar and lemon juice ( $4 \mathrm{ml} / \mathrm{kg}$ of added sugar) were cooked in an open pan with continues manual stirring. Heating was stopped when the total soluble solids (TSS) reached $68^{-} 69^{\circ}$ Brix. The hot jams were filled into glass jars $(50 \mathrm{ml})$ then tightly closed and stored at room temperature $\left(25-30^{\circ} \mathrm{C}\right)$. Table (1): showed such different jam blends.

\section{Proximate analysis}

Fig and sycamore fruits were subjected to chemical analysis as follows: the moisture, crude protein, ash, crude fiber, and ether extract were determined in fresh fruits and product according to the method of A.O.A.C (2000). Total Carbohydrates were determined by difference as follows: 
Total carbohydrates $\%=100-($ moisture $\%+$ protein $\%+$ ash $\%+$ fat $\%+$ crude fiber\%).

Table 1. ingredient percent of jam blends.

\begin{tabular}{|c|c|c|c|c|}
\hline Ingredient & $\begin{array}{c}\text { Sucrose } \\
(\mathrm{g})\end{array}$ & $\begin{array}{c}\text { Fig } \\
\mathrm{G}\end{array}$ & $\begin{array}{c}\text { sycamore } \\
\mathrm{g}\end{array}$ & $\begin{array}{l}\text { Lemon juice } \\
(\mathrm{ml}) / \mathrm{kg} \text { of added } \\
\text { sugar }\end{array}$ \\
\hline Treatments & 1000 & 1000 & -- & 4 \\
\hline $\begin{array}{c}\text { Control fig jam } \\
\text { Control sycamore } \\
\text { jam }\end{array}$ & 1000 & -- & 1000 & 4 \\
\hline F1 & 1000 & 800 & 200 & 4 \\
\hline F2 & 1000 & 200 & 800 & 4 \\
\hline F3 & 1000 & 500 & 500 & 4 \\
\hline
\end{tabular}

The mineral contents of fig and sycamore fruit, including calcium, magnesium, manganese, iron, sodium and zinc, were determined using an Atomic Absorption Flame Emission Spectrophotometer (Perkin-Elmer Model AA-6200 from Shimadzu, Japan) as reported by A.O.A.C (2000).Total sugars were determined according to Somogyi (1952).

\section{Total Soluble Solids}

Total soluble solids were determined according to direct reading of the soluble solids content on the refract meter (Ranganna 1986).

\section{Total Acidity}

Titratable acidity as citric acid in control fig, control sycamore and blends jam was determined according to (AOAC,2000)

\section{Viscosity analyses}

The viscosity analyses were determined in jam blends using the method of Shahnawaz and Shiekh, (2011).Viscosity measurements were carried out using advanced equipment, LFRA

\section{Sensory evaluation of jams}

The finished products (samples) were presented to a taste panel of 10judges from Food Technology Research Institute (FTRI) staff member. Each judge was asked to evaluate jam samples for flavor, taste, sweetness, texture and mouth fleeing on the basis of preference tests using a hedonic scale from 10 being the most liked, and 1 the most disliked according to Larmond (1977).

\section{Statistical Analysis}

Data analysis was performed using SAS (2000) software. All data were expressed as mean of three replicates and presented followed by the standard deviation or Error. Analysis of variance was used to test for differences between the 
groups. Least Significant Differences (LSD) test was used to determine significant differences ranking among the mean values at $P<0.05$.

\section{RESULTS AND DISCUSSION}

\section{Chemical composition of the tested samples and produced jam}

The result in Table (2) revealed that the moisture content of sycamore $(72.0 \%)$ is lower than that of fig $(80.0 \%)$, while moisture content of jam ranged between 18.12 to $20.9 \%$. The same data showed that all the jam samples possessed significantly lower moisture content than the fresh fruits ones after processing due to the steaming process occurred during boiling, this result were in agreement with Feugang et al., (2006). The ether extract, ash, crude fiber and carbohydrates of the sycamore fruit seemed to be significantly higher than that found in the fig fruit, which agreed with that reported by Chiteva and Wairagu (2013).

Also, in Table (2) results showed the major chemical constituents of the prepared jam of the suggested blends. The highest carbohydrates content was noticed in the tested blends jam, than that found in sycamore and fig fruits. Protein content showed a significant decrement pattern as a result of cooking process in the tested blends jams (Table2). The decrease in protein may be addition of sugar. The same Table showed that the high fiber content was noticed in the control sycamore and F2 (5.53 and 5.03\%, respectively), which agreed with that found by Chiteva and Wairagu (2013)

Table 2. The major chemical composition of the fresh fig, fresh sycamore and produced jam (on fresh weight basis \%).

\begin{tabular}{|c|c|c|c|c|c|c|}
\hline Treatment & Moisture & Protein & Ether extract & Ash & Crude Fiber & T.C* \\
\hline Fig & $80.0 \pm 0.58^{\mathrm{a}}$ & $0.833 \pm 0.0 .033^{\mathrm{a}}$ & $0.3 \pm 0.001^{\mathrm{c}}$ & $1.87 \pm 0.03^{\mathrm{d}}$ & $2.2 \pm 0.06^{\mathrm{e}}$ & $16 \pm 0.001^{\mathrm{a}}$ \\
\hline Sycamore & $72.0 \pm 0.58^{\mathrm{b}}$ & $0.70 \pm 0.06^{\mathrm{b}}$ & $0.50 \pm 0.001^{\mathrm{a}}$ & $3.5 \pm 0.06^{\mathrm{a}}$ & $6.4 \pm 0.15^{\mathrm{a}}$ & $23 \pm 0.001^{\mathrm{b}}$ \\
\hline Control fig jam & $19.08 \pm 0.58^{\mathrm{cd}}$ & $0.367 \pm 0.033^{\mathrm{e}}$ & $0.2 \pm 0.001^{\mathrm{d}}$ & $1.53 \pm 0.03^{\mathrm{f}}$ & $1.83 \pm 0.03^{\mathrm{f}}$ & $77 \pm 0.001^{\mathrm{f}}$ \\
\hline $\begin{array}{c}\text { Control } \\
\text { sycamore jam }\end{array}$ & $20.9 \pm 0.58^{\mathrm{c}}$ & $0.333 \pm 0.033^{\mathrm{cd}}$ & $0.407 \pm 0.001^{\mathrm{b}}$ & $2.87 \pm 0.03^{\mathrm{b}}$ & $5.53 \pm 0.09^{\mathrm{b}}$ & $73 \pm 0.001^{\mathrm{d}}$ \\
\hline F1 & $18.83 \pm 0.58^{\mathrm{d}}$ & $0.233 \pm 0.03^{\mathrm{d}}$ & $0.23 \pm 0.03^{\mathrm{d}}$ & $1.23 \pm 0.03^{\mathrm{g}}$ & $1.83 \pm 0.03^{\mathrm{f}}$ & $77 \pm 0.33^{\mathrm{f}}$ \\
\hline F2 & $19.09 \pm 0.58^{\mathrm{cd}}$ & $0.433 \pm 0.03^{\mathrm{c}}$ & $0.3 \pm 0.001^{\mathrm{c}}$ & $2.0 \pm 0.001^{\mathrm{c}}$ & $5.03 \pm 0.07^{\mathrm{c}}$ & $74 \pm 0.001 .33^{\mathrm{e}}$ \\
\hline F3 & $18.12 \pm 0.58^{\mathrm{d}}$ & $0.233 \pm 0.03^{\mathrm{d}}$ & $0.37 \pm 0.03^{\mathrm{b}}$ & $1.7 \pm 0.06^{\mathrm{e}}$ & $2.63 \pm 0.03^{\mathrm{d}}$ & $72 \pm 00.001^{\mathrm{c}}$ \\
\hline
\end{tabular}

Control fig $=100 \% \mathrm{fig}$, control sycamore $=100 \%$ sycamore,F1=80\%fig $+20 \%$ sycamore,F2 $=20 \%$ fig $+80 \%$ sycamore, $\mathrm{F} 3=50 \%$ fig $+50 \%$ sycamore T.C* $=$ Total carbohydrates calculated by difference, Each value (an average of three replicates) within the same column, followed by the same letter is not significantly different at $<0.05$.-Each value is followed by the standard Error . 


\section{Mineral composition:}

Data presented in Table (3) showed some minerals (i.e., Zinc, iron, calcium, potassium, sodium, magnesium, manganese and cupper) contents of fig and sycamore fruit. It revealed that the highest significant $\mathrm{Zn}, \mathrm{Fe}$, and $\mathrm{Mn}$ amount were noticed in fig than found in sycamore fruits. Calcium, potassium, sodium, magnesium and cupper contents of the sycamore fruit were significantly increased than that found in the fig fruit. The obtained results are in agreement with those reported by Slavin (2006), who reported that sycamore species are an excellent source of minerals, vitamins and dietary fiber

Table 3. Mineral contents of fresh fig, fresh sycamore and formulae jam (calculate as $\mathrm{mg} / 100 \mathrm{~g}$ wet sample)

\begin{tabular}{|c|c|c|c|c|c|c|c|c|}
\hline Treatment & $\mathrm{Zn}$ & $\mathrm{Fe}$ & $\mathrm{Ca}$ & $\mathrm{K}$ & $\mathrm{Mg}$ & $\mathrm{Na}$ & $\mathrm{Mn}$ & $\mathrm{Cu}$ \\
\hline $\mathrm{Fig}$ & $15 \pm 0.58^{\mathrm{a}}$ & $37 \pm 0.58^{\mathrm{a}}$ & $35 \pm 0.58^{\mathrm{e}}$ & $242 \pm 0.58^{\mathrm{e}}$ & $17.67 \pm 0.33^{\mathrm{d}}$ & $1.5 \pm 0.058^{\mathrm{d}}$ & $128 \pm 0.58^{\mathrm{a}}$ & $0.02 \pm 0.006^{\mathrm{abc}}$ \\
\hline sycamore & $12.6 \pm 0.58^{\mathrm{bc}}$ & $25 \pm 0.58^{\mathrm{c}}$ & $316.5 \pm 0.58^{\mathrm{a}}$ & $382 \pm 0.58^{\mathrm{a}}$ & $63.47 \pm 0.64^{\mathrm{a}}$ & $16 \pm 0.58^{\mathrm{a}}$ & $36 \pm 0.58^{\mathrm{e}}$ & $0.037 \pm 0.009^{\mathrm{a}}$ \\
\hline
\end{tabular}

Control fig $=100 \%$ fig, control sycamore $=100 \%$ sycamore,F1=80\%fig $+20 \%$ sycamore,F2 $=20 \%$ fig $+80 \%$ sycamore,F3=50\%fig $+50 \%$ sycamore -Each value (an average of three replicates) within the same column, followed by the same letter is not significantly different at $<0.05$.-Each value is followed by the standard Error .

\section{Sensory evaluation:-}

One of limiting factor for consumer acceptability is the sensory properties. Therefore, flavor, taste, sweetness, texture and mouth fleeing of consumer were determined and data were found in Table (4). It confirmed that control fig, F1, F2 and F3 possessed the best flavor, with significant difference, while control sycamore jam was recorded the lowest value of flavor. With respect to the taste of the tested jam, F2 and F3 were the most preferable by panelist and also, F2 and F3 were no significant difference. Meanwhile, there were significant differences between the other tested samples including control fig jam. Data showed that no significant differences between the sweetness, in both F2 and F3 samples. The sweetness attribute seemed to follow the same pattern of the taste attribute, where in there were significant difference among the tested jam samples. Statistical analysis showed a significant difference in acceptability among different treatments. The texture score was greatly affected by the proportion of sycamore replacing fig, while texture was improved by the addition of sycamore up to $50 \%$ of fig jam. Mouth fleeing evaluation of the tested jam showed that control fig jam was the most preferable by the panelist followed by the F2 and F3 with no significant difference, wherein, there was significant difference among the 
tested jam samples. In general, the tested jam blends seemed to be more preferable jam than control sycamore, due to it showed the lowest degree of consumer acceptability with respect to all organoleptic properties. These results are in agreement with that found by Vidhya and Narain (2011) they reported that the jam is more or less a concentrated fruit processing which has fairly thick consistency and body. It is also rich in flavor, because ripe fruits which have developed full flavor are used in its preparation. A great advantage in its preparation is that it can be prepared in a single operation. In jam production since there is no addition of color or flavor the sensory characteristics such as appearance and taste are dependent on the fruit quality and the kind of fruit used for example fresh fruit, frozen fruit and fruit puree. As the sugar content increases, there was increasing hardness in the jam making it less acceptable to tasters.

Table 4. Sensory properties of jam

\begin{tabular}{|c|c|c|c|c|c|}
\hline \multirow{2}{*}{ Treatments } & \multicolumn{5}{|c|}{ Sensory characteristics of the jam } \\
\cline { 2 - 6 } & Flavor & Taste & Sweetness & Texture \\
$(10)$ & $(10)$ & $(10)$ & Mouth feeling \\
& & $10)$ & $(10)$ \\
\hline Control fig jam & $9.4 \pm 0.221^{\mathrm{a}}$ & $9.4 \pm 0.221^{\mathrm{a}}$ & $9.1 \pm 0.233^{\mathrm{a}}$ & $9.5 \pm 0.224^{\mathrm{a}}$ & $9.3 \pm 0.260^{\mathrm{a}}$ \\
\hline Control & & & & & \\
\hline sycamore jam & $5.6 \pm 0.221^{\mathrm{d}}$ & $5.8 \pm 0.249^{\mathrm{d}}$ & $5.7 \pm 0.300^{\mathrm{d}}$ & $5.6 \pm 0.221^{\mathrm{e}}$ & $5.7 \pm 0.213^{\mathrm{d}}$ \\
\hline F1 & $6.4 \pm 0.306^{\mathrm{c}}$ & $6.4 \pm 0.267^{\mathrm{c}}$ & $8.1 \pm 0.233^{\mathrm{b}}$ & $6.0 \pm 0.298^{\mathrm{d}}$ & $6.7 \pm 0.300^{\mathrm{c}}$ \\
\hline F2 & $8.1 \pm 0.277^{\mathrm{b}}$ & $8.3 \pm 0.335^{\mathrm{b}}$ & $6.8 \pm 0.327^{\mathrm{c}}$ & $8.1 \pm 0.348^{\mathrm{b}}$ & $7.9 \pm 0.379^{\mathrm{b}}$ \\
\hline F3 & $7.4 \pm 0.340^{\mathrm{b}}$ & $7.3 \pm 0.335^{\mathrm{b}}$ & $7.3 \pm 0.260^{\mathrm{c}}$ & $7.2 \pm 0.291^{\mathrm{c}}$ & $7.4 \pm 0.221^{\mathrm{bc}}$ \\
\hline
\end{tabular}

Control fig $=100 \%$ fig, control sycamore $=100 \%$ sycamore,F1 $=80 \%$ fig $+20 \%$ sycamore,F2 $=20 \%$ fig $+80 \%$ sycamore,F3=50\% fig $+50 \%$ sycamore -Each value (an average of three replicates) within the same column, followed by the same letter is not significantly different at $<0.05$.-Each value is followed by the standard Error .

\section{Physicochemical characteristics of the tested jam}

Data regarding physicochemical characteristics of the tested jam are presented in Table 6,7 and 8 during storage period. The results presented in Table (6) showed that the total sugar for the jam prepared form fig, sycamore fruits and their blends with different ratio at zero time and during storage periods, the same Table showed that significant differences in the total sugar were found among such tested jam. Total sugars show a slight significant increment for all blends jam, mainly due to addition of sugar as well as thermal process that reduced water content. 
Table 6. Total sugar $(\mathrm{g} / 100 \mathrm{~g})$ of jam during storage period at room temperature

\begin{tabular}{|c|c|r|r|r|c|}
\hline \multirow{2}{*}{ Treatments } & \multicolumn{5}{|c|}{$\begin{array}{l}\text { Storage } \\
\text { period }\end{array}$} \\
\cline { 2 - 6 } & At zero time & 3 month & 6 month & 9 month & 12 month \\
\hline Control fig jam & $68.10 \pm 0.1^{\mathrm{a}}$ & $68.24 \pm 0.053^{\mathrm{a}}$ & $68.45 \pm 0.05^{\mathrm{a}}$ & $68.49 \pm 0.1^{\mathrm{a}}$ & $68.50 \pm 0.1^{\mathrm{a}}$ \\
\hline $\begin{array}{c}\text { Conterol } \\
\text { sycamore jam }\end{array}$ & $67.23 \pm 0.09^{\mathrm{b}}$ & $67.28 \pm 0.035^{\mathrm{b}}$ & $67.55 \pm 0.095^{\mathrm{c}}$ & $67.70 \pm 0.03^{\mathrm{c}}$ & $67.82 \pm 0.025^{\mathrm{b}}$ \\
\hline F1 & $66.70 \pm 0.2^{\mathrm{c}}$ & $66.82 \pm 0.076^{\mathrm{c}}$ & $66.9 \pm 0.04^{\mathrm{d}}$ & $66.8 \pm 0.1^{\mathrm{d}}$ & $67.9 \pm 0.26 \mathrm{c}$ \\
\hline F2 & $68.22 \pm 0.08^{\mathrm{a}}$ & $68.26 \pm 0.015^{\mathrm{a}}$ & $68.38 \pm 0.11^{\mathrm{a}}$ & $68.5 \pm 0.03^{\mathrm{a}}$ & $68.33 \pm 0.23^{\mathrm{b}}$ \\
\hline F3 & $67.3 \pm 0.2^{\mathrm{b}}$ & $67.55 \pm 0.35^{\mathrm{b}}$ & $67.71 \pm 0.05^{\mathrm{b}}$ & $67.86 \pm 0.06^{\mathrm{b}}$ & $68.00 \pm 0.2^{\mathrm{b}}$ \\
\hline
\end{tabular}

Control fig $=100 \%$ fig, control sycamore $=100 \%$ sycamore,F1 $=80 \%$ fig $+20 \%$ sycamore, $\mathrm{F} 2=20 \% \mathrm{fig}$ $+80 \%$ sycamore, $\mathrm{F} 3=50 \%$ fig $+50 \%$ sycamore - Each value (an average of three replicates) within the same column, followed by the same letter is not significantly different at $<0.05$.-Each value is followed by the standard Error .

In case of acidity, Table (7) showed that the acidity for the jam prepared form fig , sycamore and blended with different ratio at zero time and during storage periods, acidity show a slight significant increment for all jam samples. The same Table showed that significant differences in acidity were found among the blends jam during storage period. Also, the results showed that the acidity (\%) was no significantly in control fig and F2 blend jam during storage period. F2 had the highest (1.57\%) and F3 had the lowest (1.03\%) value for acidity during storage period. This results are in agreement with (Rathore et al., 2007) who reported that variation in acidity among different varieties might be due to the activity of citric acid or lemon during cooking process which lead to the degradation of citric acid.

Table 7. Acidity \% (as citric acid) of jam during storage period at room temperature

\begin{tabular}{|c|r|r|r|r|r|}
\hline \multirow{2}{*}{ Treatments } & \multicolumn{5}{|c|}{ Storage period } \\
\cline { 2 - 5 } & At zero time & 3 month & 6 month & 9 month & 12 month \\
\hline $\begin{array}{c}\text { Control fig } \\
\text { jam }\end{array}$ & $1.18 \pm 0.003^{\mathrm{c}}$ & $1.25 \pm 0.009^{\mathrm{c}}$ & $1.35 \pm 0.009^{\mathrm{c}}$ & $1.45 \pm 0.015^{\mathrm{b}}$ & $1.58 \pm 0.007^{\mathrm{c}}$ \\
\hline $\begin{array}{c}\text { Control } \\
\text { sycamore jam }\end{array}$ & $1.35 \pm 0.006^{\mathrm{b}}$ & $1.47 \pm 0.009^{\mathrm{b}}$ & $1.55 \pm 0.006^{\mathrm{b}}$ & $1.76 \pm 0.009^{\mathrm{a}}$ & $1.78 \pm 0.009^{\mathrm{b}}$ \\
\hline F1 & $1.13 \pm 0.012^{\mathrm{c}}$ & $1.23 \pm 0.009^{\mathrm{c}}$ & $1.35 \pm 0.017^{\mathrm{c}}$ & $1.45 \pm 0.018^{\mathrm{b}}$ & $1.58 \pm 0.006^{\mathrm{c}}$ \\
\hline F2 & $1.57 \pm 0.009^{\mathrm{a}}$ & $1.63 \pm 0.012^{\mathrm{a}}$ & $1.67 \pm 0.006^{\mathrm{a}}$ & $1.77 \pm 0.01^{\mathrm{a}}$ & $1.85 \pm 0.015^{\mathrm{a}}$ \\
\hline F3 & $1.03 \pm 0.01^{\mathrm{d}}$ & $1.13 \pm 0.12^{\mathrm{d}}$ & $1.24 \pm 0.4^{\mathrm{d}}$ & $1.36 \pm 0.02^{\mathrm{c}}$ & $1.45 \pm 0.017^{\mathrm{d}}$ \\
\hline
\end{tabular}

Control fig $=100 \%$ fig, control sycamore $=100 \%$ sycamore,F1 $=80 \%$ fig $+20 \%$ sycamore,F2 $=20 \%$ fig $+80 \%$ sycamore, $\mathrm{F} 3=50 \% \mathrm{fig}+50 \%$ sycamore - Each value (an average of three replicates) within the same column, followed by the same letter is not significantly different at $<0.05$.-Each value is followed by the standard Error . 
Table 8. Viscosity, pH value and total soluble solids of jam after storage at room temperature

\begin{tabular}{|c|c|c|c|c|c|}
\hline Parameters & Control fig jam & Control sycamore jam & $\mathrm{F} 1$ & $\mathrm{~F} 2$ & F3 \\
\hline \multicolumn{6}{|l|}{ Viscosity (poise) } \\
\hline 0 & $33486.56 \pm 0.006^{\mathrm{e}}$ & $42285.87 \pm 0.12^{\mathrm{d}}$ & $50628.88 \pm 0.009^{b}$ & $54400.55 \pm 0.009^{\mathrm{a}}$ & $50285.99 \pm 0.029^{c}$ \\
\hline 3 & $33485.23 \pm 0.006^{\mathrm{e}}$ & $42285.84 \pm 0.009^{d}$ & $50628.81 \pm 0.015^{b}$ & $54400.35 \pm 0.012^{\mathrm{a}}$ & $50285.79 \pm 0.012^{c}$ \\
\hline 6 & $33485.23 \pm 0.009^{e}$ & $42285.76 \pm 0.009^{d}$ & $50628.780 .009^{\mathrm{b}}$ & $54400.320 .009^{a}$ & $50285.55 \pm 0.035^{c}$ \\
\hline 9 & $33485.12 \pm 0.009^{\mathrm{e}}$ & $42285.570 .012^{d}$ & $50628.68 \pm 0.012^{b}$ & $54400.25 \pm 0.015^{\mathrm{a}}$ & $50285.39 \pm 0.09 c$ \\
\hline 12 & $33485.71 \pm 0.018^{\mathrm{e}}$ & $42285.45 \pm 0.035^{d}$ & $50628.58 \pm 0.012^{b}$ & $54400.00 \pm 0.12^{\mathrm{a}}$ & $50285.19 \pm 0.006^{c}$ \\
\hline \multicolumn{6}{|l|}{$\mathrm{pH}$} \\
\hline 0 & $3.80 \pm 0.058^{\mathrm{b}}$ & $4.50 \pm 0.058^{\mathrm{a}}$ & $3.8 \pm 0.06^{\mathrm{b}}$ & $4.60 \pm 0.07^{\mathrm{a}}$ & $4.45 \pm 0.03^{\mathrm{a}}$ \\
\hline 3 & $3.70 \pm 0.058^{\mathrm{b}}$ & $4.35 \pm 0.003^{\mathrm{a}}$ & $3.8 \pm 0.007^{b}$ & $4.36 \pm 0.007^{\mathrm{a}}$ & $3.99 \pm 0.08^{\mathrm{b}}$ \\
\hline 6 & $3.66 \pm 0.007^{b}$ & $4.16 \pm 0.007^{\mathrm{a}}$ & $3.64 \pm 0.007^{\mathrm{a}}$ & $3.77 \pm 0.003^{b}$ & $3.77 \pm 0.008^{\mathrm{b}}$ \\
\hline 9 & $3.67 \pm 0.03^{\mathrm{ab}}$ & $3.77 \pm 0.03^{\mathrm{a}}$ & $3.58 \pm 0.007^{b}$ & $3.65 \pm 0.01^{\mathrm{ab}}$ & $3.53 \pm 0.013^{b}$ \\
\hline 12 & $4.45 \pm 0.012^{\mathrm{a}}$ & $3.94 \pm 0.047^{b}$ & $3.77 \pm 0.01^{c}$ & $3.51 \pm 0.02^{\mathrm{d}}$ & $3.48 \pm 0.03^{d}$ \\
\hline \multicolumn{6}{|l|}{ T.S.S } \\
\hline 0 & $68.266 \pm 0.09^{b}$ & $68.2 \pm 0.06^{\mathrm{b}}$ & $68.2 \pm 0.12^{b}$ & $68.37 \pm 0.07^{\mathrm{ab}}$ & $68.6 \pm 0.03^{\mathrm{ab}}$ \\
\hline 3 & $68.66 \pm 0.03^{\mathrm{ab}}$ & $68.33 \pm 0.03^{b}$ & $68.37 \pm 0.07^{b}$ & $68.9 \pm 0.06^{\mathrm{a}}$ & $68.8 \pm 0.06^{\mathrm{ab}}$ \\
\hline 6 & $68.83 \pm 0.07^{\mathrm{ab}}$ & $68.47 \pm 0.03^{b}$ & $68.63 \pm 0.07^{b}$ & $69.23 \pm 0.12^{\mathrm{ab}}$ & $68.87 \pm 0.03^{b}$ \\
\hline 9 & $69.53 \pm 0.15^{\mathrm{a}}$ & $68.63 \pm 0.09^{b}$ & $68.63 \pm 0.09^{b}$ & $69.23 \pm 0.1^{\mathrm{ab}}$ & $69.3 \pm 0.06^{\mathrm{a}}$ \\
\hline 12 & $69.53 \pm 0.09^{\mathrm{a}}$ & $68.87 \pm 0.03^{\mathrm{a}}$ & $69.53 \pm 0.09^{\mathrm{a}}$ & $69.7 \pm 0.12^{\mathrm{a}}$ & $69.5 \pm 0.03^{\mathrm{a}}$ \\
\hline
\end{tabular}

Control fig $=100 \%$ fig, control sycamore $=100 \%$ sycamore,F1= $80 \%$ fig $+20 \%$ sycamore,F $2=20 \%$ fig $+80 \%$ sycamore,F3=50\%fig $+50 \%$ sycamore

-Each value (an average of three replicates) within the same column, followed by the same letter is not significantly different at $<0.05$.-Each value is followed

by the standard Error . 
Table (8) showed that the some physicochemical characteristics $(\mathrm{pH}$, total soluble solid and viscosity).The viscosity measurement of food product is much useful behavioral and predictive information to take guidelines in formulation, processing and product development (Shahnawaz and Shiekh ,2011). Results as shown in Table (8) indicated that jam has ranged between 54400.55 to 33486.56 (poise) viscosity which is absolutely high at zero time storage. Also, the data indicated that there is no significant difference between the mean scores viscosity at the same jam blends during storage periods. From the same Table (8) it could be noticed that there is significant difference the mean scores viscosity at the storage period within the jam blends jam. F2 had the highest value and control fig jam had the lowest value for viscosity during storage period. Viscosity standards for low and high viscosity ranged from, 20000 to 40000 poise. These results agreed with Shahnawaz and Shiekh, (2011) they reported that, there is a significant change in viscosity when the fruit products are made through heating or cooking. This influences on velocity and temperature profiles, therefore, it is necessary to have knowledge about the influence of shear-rate, shear-stress and cooking temperature on the rheological behavior of fruit products.

Data presented in Table (8) indicated that a slight significant difference between the mean $\mathrm{pH}$ scores for at the same blends jam and all blends jam during storage periods. From the same Table (8) it could be noticed that a slight significant decrement in the mean $\mathrm{pH}$ scores at the storage period within the blends jam. This may due partly to their varying composition. Similarly same observation was made on $\mathrm{pH}$ of jam prepared from grape fruit apple marmalade by Iftikhar et al.,(2007). On contrary the control fig jam had the highest value of $\mathrm{pH}$ than found in the other jam blends after 12 month storage period. The same table showed that the total soluble solid ('Brix) of treatment F3 (50\% fig and 50\% sycamore) and F2 (20\% fig and $80 \%$ sycamore) were higher than that of control fig jam, F1 (80\% fig and 20\% sycamore ) and control sycamore jam . Total soluble solid showed a slight significant increase for blends jam during storage period, which may be due to the enzymatic conversion of mono saccharides into sugar molecules and degradation of pectin resulting in an increase of total soluble solids. These results agreement with Shahnawaz and Shiekh , (2011).

\section{CONCLUSION}

The trend towards product development from natural sources has increased. The fresh fig and sycamore fruits contained considerable amount of, fibers, total sugar, ash and minerals. And other important nutrients, which make fig and sycamore fruits 
suitable to produce jam rich in several nutrients besides excellent color, flavor, appearance and taste. In conclusion, the incorporation of sycamore (up to $50 \%$ ) and fig in jam production increased the sensory acceptability and increased its nutritive value. Thus, one may recommend the use of sycamore as a fig substitute in the production of various jams to increase their nutritive values and to increase sycamore utilization. Also, we recommend expanding the cultivation of sycamore trees in the new land and its use in food processing and pharmaceutical products.

\section{REFERENCES}

1. A.O.A.C. 2000. Association of Official Analytical Chemist. $17^{\text {th }} \mathrm{Ed}$, Published by the association of Official Anlytical Chemists, USA.

2. Chiteva, R and Wairagu,N. 2013. Chemical and nutritional content of Opuntia ficus-indica (L.) . African Journal of Biotechnology ,vol 12(21):3309-3312.

3. El-Sayyad, S. M. , Makboul, M. A. , Farag, S. F. and Ali, R. M. 2014. Macro and micromorphology of the leaves, inforesences and fruits of Ficus Sycomorus $L$ cultivated in Egypt:Part 1 . Bull. Pharm. Sci., Assiut University, Vol. 37, pp. 1-25.

4. FAO. 2010. Food and Agriculture Organization, report 2012. Forest Ressources Assessment.

5. Feugang, M.J., Konarski, P., Zou, D., Stintzing, F.C., Zou, C. 2006. Nutritional and medicinal use of Cactus pear (Opuntia spp.) cladodes and fruits. Frontiers in Bioscience 11:2574-2

6. Iftikhar, S, Yasser, D , Imtiaz, H, Ihsan, M. QandAlam ,Z. 2007. Physicochemical Analysis of Apple and Pear Mixed Fruit Jam Prepared from Varieties Grown in Azad Jammu and Kashir Internet J. Fd Safety, Vol.9, p. 22-24

7. Larmond, E. 1977. "Laboratory Methods for Sensory Evaluation of Foods." Research Branch, Canadian Dept. of Agric. Pub. 1637.

8. Rafael, S. C., Adriano, G. C, Rubens, R. N, Wellington,F. C, Assis, F. Fand Helena, M.A.B. 2013. Sensory profile and physicochemical characteristics of mango nectarsweetened with high intensity sweeteners throughout storage time. Food Research International 54 : 1670-1679

9. Ramde-Tiendrebeogo, A., Andre, T, Adam, H, Marius, L, Hassanat, M.K, Odile G.N and Innocent, P. G. 2012. Antioxidative and antibacterial activities of phenolic compounds from Ficus sur Forssk. and Ficus sycomorus L. (Moraceae) : potential for sickle cell disease treatment in Burkina Faso Int. J. Biol. Chem. Sci. 6(1): 328-336 
10. Ranganna, S. 1986. Handbook of Analysis and Quality Control for Fruit and Vegetable Products. 2nd ed. Tata McGraw Hill Publishing Company Ltd., New Delhi, India. p.12.

11. Rathore, H.A., T. Masud, S. Sammi and A.H. Soomro. 2007. Effect of storage on physic-chemicalcomposition and sensory properties of mangoMagnifera indica L.) variety Dosehari. Pak. J. Nutr., 6: 143-148.

12. Rodriguez-Garcia ME, de Lira C., Hernandez-Becerra E, Cornejo- Villegad MA, Palacios-Fonseca AJ, Rojas- Molina I, Reynoso R, Quintero LC, del Real A, Zepeda A, Munoz-Torres C. 2007. Physicochemical characterization of Nopal pads (Opuntia ficus indica) and dry vacuum nopal powder as a function of the maturation. Plant Foods Hum. Nutr. 62(3):107-112.

13. SAS. 2000. SAS, Statistical Analysis System SAS users guide: statistics, SAS Inc. Editors, cary,USA,2000

14. Shahnawaz,M and Shiekh, A.S. 2011. Analysis of viscosity of jam fruit juice, squash and jam at different compositions to ensure the suitability of processing applications.

15. International Journal of Plant Physiology and Biochemistry Vol. 3(5) pp.89-94,

16. Slavin, J.L., 2006. Figs: past, Present, Future. Nutrition Tody, 41: 180-184.

17. Somogyi,M. 1952. Notes on sugar determination. J. Biol.Chem., 195,19-23

18. Van Noort, S., Gardiner, A.J. and Tolley, K.A. 2007. New records of Ficus (Moraceae) species emphasize the conservation significance of inselbergs in Mozambique. South Afr. J. Bot. 73:642-649.

19. Vidhya, R. and Narain, A. 2011. Formulation and Evaluation of Preserved Products Utilizing under Exploited Fruit, Wood Apple (Limonia acidissima). American-Eurasian J. Agric. \& Environ. Sci., 10 (1): 112-118 


\section{انتاج وتقييم خلطات مربى الجميز والتين}

$$
\text { معرة بحوث تكنولوجيا الاغذية - مركز البحوث الزراعية - جيزة - مصر. }
$$

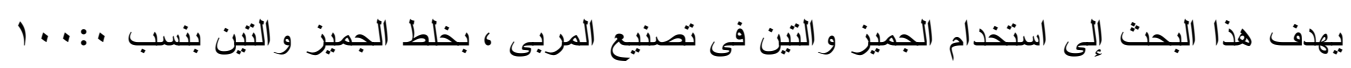

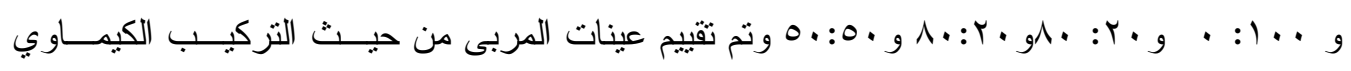

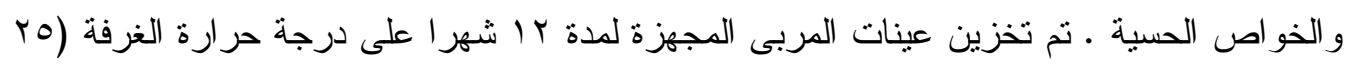

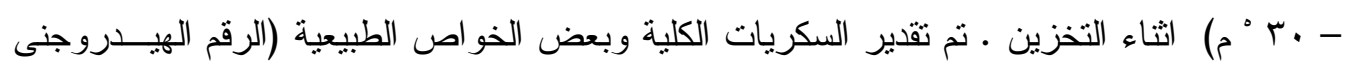
-المو اد الصلبة الكلية و اللزوجة). و ايضا أظهرت النتائج ان استبدال التين يزيد من الرماد و البروتين

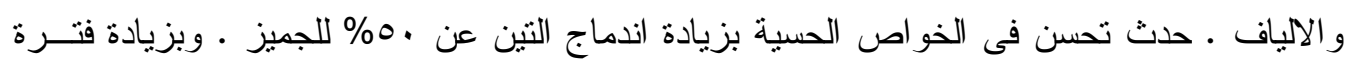

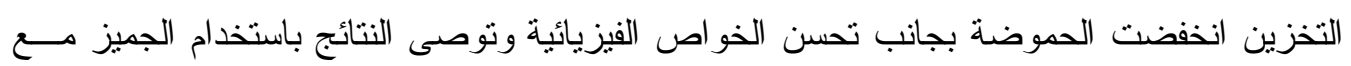

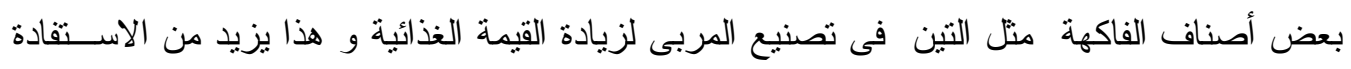

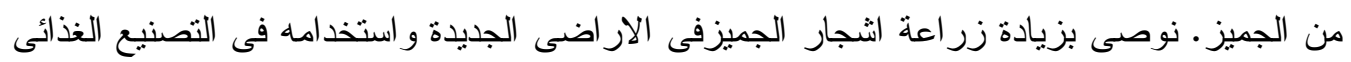
و المنتجات الدو ائية. الكلمات الافتتاحية : الجميز -التين - المربى - التقييم الحسى -الدو اد الصلبة الذائبة - اللزوجة 